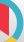

\title{
Anti-Escherichia coli Activity of Herbal Medicines: A Systematic Literature Review
}

\author{
Khadijeh Saravani ${ }^{1, *}$ and Fardin Ali Malayeri ${ }^{2}$ \\ ${ }^{1}$ Assistant Professor of Forensic Medicine and Toxicology, Faculity of Medicine, Zabol University of Medical Sciences, Zabol, Iran \\ ${ }^{2}$ Department of clinical biochemistry, Faculity of Medicine, Zabol University of Medical Sciences, Zabol, Iran \\ "Corresponding author: Faculity of Medicine, Zabol University of Medical Sciences, Zabol, Iran. Email: k.saravani@yahoo.com \\ Received 2019 July 28; Revised 2020 April 21; Accepted 2020 April 25.
}

\begin{abstract}
Context: Infectious diseases are the cause of death worldwide. As antibiotic resistance is rising, researchers are looking for new therapies. The Gram-negative bacterium Escherichia coli, causes acquired hospital infections and results in intestinal infections and many infections out of the intestine, like urinary tract infections (UTI), cholecystitis, wound infections, meningitis, septicemia, pulmonary infections, etc. Plants are a good source of bioactive compounds; hence, they can be effective in treating several illnesses. The purpose of this research was to peruse the antibacterial activity of various herbal extracts on E. coli.

Evidence Acquisition: This research was obtained from various articles published from 2000 to 2017 from the PubMed, ScienceDirect, Springer, Islamic Science Citation, and Magiran databases. The keywords used were E. coli, herbs, natural antibiotics, and antimicrobial activity.

Results: The results showed that the ethanolic extracts of medicinal plants showed better inhibitory function against $E$. coli than other solvents.

Conclusions: The obtained results showed that medicinal herbs can be considered as the main medicinal agents capable of affecting infections caused by E. coli.
\end{abstract}

Keywords: Antimicrobial Activity, Plant Extracts, Herbal Extracts, Escherichia coli

\section{Context}

The use of herbal medicinal compounds has long been considered by a human being. The drugs that are used widely worldwide to cure several diseases, including bacterial, viral, and fungal infections, and all kinds of metabolic diseases, even cancer, are naturally occurring compounds (1-3). The herbal medicines containing herbal compounds and their derivatives account for about one-third of the total available drugs $(4,5)$. One of the main reasons for the desire of the medical community to use herbal compounds is their low side effect compared with chemical drugs, which has been proved during many years in traditional medicine $(6,7)$. In addition, the use of industrial medicines and chemical compounds can lead to undesirable metabolic reactions, and, in most cases, free radicals and peroxides are produced. Herbal medicines are rich in various bioactive compounds that prevent the production of oxidants (8).

Enterohemorrhagic Escherichia coli is one of six types of $E$. coli recognized as the cause of diarrhea. It provides cytotoxins, such as verocytotoxin or Shiga-like toxin, which causes hemorrhagic colitis. This organism was first identified as a cause of illness in 1982, and its related diseases have been increased. E. coli has recently been widely considered as it is easily transferred by human and animal waste and contaminates the environment $(9,10)$.

E. coli is an opportunistic pathogen that is frequently colonized in the human colonic region (11). At the equal opportunity, it is one of the most prevalent causative agents for the urinary tract injury (UTI) and abdominal diseases. The most important virulence part of microorganisms, especially Gram-negative bacteria, is adhesion to the host cell receptors. This adhesion is caused by particular adhesins, which are surrounded in fimbriae, e.g., pili (pilus adhesion) in Gram-negative bacteria and are on the cell wall (non-pilus adhesion) in Gram-positive bacteria.

E. coli can acquire antimicrobial resistance mechanisms, such as encoding the genes of the enzymes, such as $\beta$-lactamases, the genes that alter the bacterial cell wall, which results in no binding site for antimicrobial agent and condensation of outlet pumps, translation, and transduction (12). Efflux pumps are transportation proteins 
involved in the extrusion of toxic substrates (including nearly all types of clinically important antibiotics) (13). Efflux pumps can be discriminated from multidrug efflux pumps, and the extrusion of antimicrobial agents via these efflux pumps is a major factor in antimicrobial resistance (14). Cells can use proton-driven antiporters and/or ATP-driven transporters (ATP-binding cassette) to expel medicines (15). Efflux pump inhibitors can be utilized to reduce the efflux of antibiotics from bacterial cells, suggesting that antibiotics, such as ciprofloxacin can be used to restore medicinal protection. Verapamil and MC207,110 are common utilized efflux pump inhibitors (15). As a consequence of antibiotic defense, new antimicrobials that will be restored or used with antibiotics are needed.

\section{Evidence Acquisition}

Studies in English published from 2000 to 2017 were searched using Web of Science, PubMed, Scopus, Google Scholar, and ScienceDirect using the keywords Escherichia coli, Plant extracts, herbal plants, herbal medicines, and antibacterial activity. Further citations were recognized by evaluating the reference lists of related articles.

\section{Results}

The reported minimum inhibitory concentration (MIC) values of the used plants against E. coli are summarized in Table 1. As can be found, the majority of the studied plants had bacteriostatic activity, and some had both bacteriostatic and as well as bactericidal activity.

\section{Discussion}

Several studies have revealed that herbal medicines are good sources of compounds with antioxidant and antimicrobial activity, which are able to protect the body against cellular oxidation and pathogens. Therefore, the classification of various herbal medicines because of their antioxidant and antimicrobial potentials is considerable. Herbal drugs that are safe and protect against pathogens are beneficial candidates for generating new antimicrobial medicines and have been long used in many cultures.

The main medicinal plants and their major compounds that can affect E. coli are as follows: Allicin (S-(2-propenyl) 2-propene-1-sulfinothioate) is the most biologically active sulfur-containing compound of garlic (A. sativum) (56), thymol, $\gamma$-terpinene, para-cymene, and $\alpha$ - and $\beta$-pinene are the most biologically active sulfur-containing compounds of Trachyspermum ammi), the major compounds identified in the essential oil of
Hibiscus sabdariffal are hexadecanoic acid and linoleic acid; Carvacrol and Thymol are the most frequent compounds of the Zataria multiflora $\mathrm{Z}$ (57); linalool and $\beta$ pinene are the most biologically active sulfur-containing compound of Aloe vera and Teucrium polium (58); in $\mathrm{Eu}$ calyptus globulus, 1,8-cineole, globulol, trans-pinocarveol, and alpha-terpineol are the main components (59); Cuminaldehyde, p-cymene, $\beta$-pinene, $\alpha$-terpinen-7-al, $\gamma$ terpinene, p-cymen-7-ol, and thymol are found in Cyminum cuminum (60), n-tetracosane, n-eicosane, tetratriacotane, 7-octadecanal, and tricosane are the major constituents in Coccinia grandis (61), (the major compounds in the leaf essential oil of Laportia ovalifolia and Spondias mombin are $\delta$-cadinene, $\alpha$-humulene, $\gamma$-muurolene, $\alpha$-gurjunene, $\alpha$-muurolene, 5-isocedranol, and $\delta$-cadinene) (62), in Ficus exasperate, the significant compounds are 1,8-cineole, (E)-phytol, and p-cymene) (63), and sesquiterpene $\beta$ caryophyllene (flower: $15.2 \%$, stem: $8.1 \%$ ) are highly found in Ageratum conyzoides; six of the identified compounds, including $\beta$-copaene, hexanal, trans-cadina-1(6),4-diene, $\alpha$-calacorene, $\quad$ caryophylla-4(12),8(13)-diene-5- $\beta$-ol, $\quad$ and 1,10-di-epi-cubenol are reported for the first time as constituents of A. conyzoides) (64); the main chemical constituents in Punica granatum peel seeds were propanoic acid, benzenedicarboxylic acid, methoxypropionic acid, and methylamine (65), regarding Quercus Infectoria, both phenolic and flavonoid compounds are found in the methanol extract; however, phenolic compounds are more than the flavonoid compounds (66); phenolic compounds, flavonoids, saponins, steroids, tannins, xanthoproteins, carboxylic acids, coumarins, and carbohydrates were detected in the methanol extract of Peltophorum pterocarpum flowers (67); in P. granatum, Cissus welwitschii, Triumfetta welwitschii, Entada Africana (bark), Lannae acida (stem bark), and Terminalia avicennoides, bioactive hydrolysable tannin compounds, including ellagic acid, punicalagin, flavogallonic acid, and terchebulin) (68) are highly available; four flavonoids, such as 6,7-(2",2"-dimethyl chromeno)-8- $\gamma, \gamma$-dimethyl allyl flavanone, 3',4'dihydroxy-7,8 (2",2"- dimethyl chromeno)6- $\gamma, \gamma$ dimethyl allyl flavonol, 7-methyltectorigenin, and Irisolidone were isolated from the leaves of Lannea acida) (69); $\alpha$-pinene, E- $\beta$-ocimene, terpinolene, $\alpha$-terpineol, eugenol, $\beta$-cubenene, $\beta$-caryophyllene, $\gamma$ - muurolene, -muurolene, epi-cubebol, and -cubebol, and $\delta$-cadinene in less quantity were detected in Ocimum gratissimum (70); and new anthraquinones, namely 1-hydroxy-2,7-dimethyl anthraquinone, 2-hydroxy -6-methyl anthraquinone, 2,6-dihydroxy anthraquinone, 1-hydroxy 2-methyl anthraquinone, nordamnacanthal, physcion, 1,4-dihydroxy 6-methyl-anthraquinone, 1,4-dihydroxy 2-methyl anthraquinone, 1,5-dihydroxy 2-methyl anthraquinone, 3- 
prenyl methoxy 1,4-naphthoquinone, 1-hydroxy 2-methoxy anthraquinone, 1,4-dihydroxy 2-methyl 5-methoxy anthraquinone or 1,4-dihydroxy 2-methyl 8-methoxy anthraquinone, 1,3-dimethoxy 2-carboxy anthraquinone, and rubiadin were isolated from Rubia cordifolia roots) (71). Additional information about medicinal plants effective against E. coli are presented in Table 1.

\section{Conclusions}

The strains of E. coli have consistently been shown resistance to various antibiotics, which has increased their pathogenicity; thus, finding new strategies to treat infections caused by them is of great importance.

\section{Acknowledgments}

The authors appreciate all people who helped in this research.

\section{Footnotes}

Authors' Contribution: None declared by the authors. Conflict of Interests: The authors declared no conflict of interest.

Funding/Support: This study was supported by the Zabol University.

\section{References}

1. Tchakam PD, Lunga PK, Kowa TK, Lonfouo AHN, Wabo HK, Tapondjou LA, et al. Antimicrobial and antioxidant activities of the extracts and compounds from the leaves of Psorospermum aurantiacum Engl. and Hypericum lanceolatum Lam. BMC Complementary Altern Med. 2012;12(1):136. doi: 10.1186/1472-6882-12-136. [PubMed: 22916964].

2. Davari A, Solouki M, Fazeli-Nasab B. [Effects of jasmonic acid and titanium dioxide nanoparticles on process of changes of phytochemical and antioxidant in genotypes of Satureja hortensis]. Eco-Phytochem J Med Plants. 2018;5(4):1-20. Persian.

3. Fazeli-Nasab B. Evaluation of Antibacterial Activities of Hydroalcoholic Extract of Saffron Petals on Some Bacterial Pathogens. J Med Bacteriol. 2019;8(5, 6):8-20.

4. Safavi F, Ebrahimi P, Mighani H. In vitro antibacterial activity of root and aerial parts of Scrophularia striata Bioss on Escherichia coli, Staphylococcus aureus and Bacillus cereus. Armaghane Dnesh. 2013;18(8):603-14.

5. Rezaei-Nasab M, Komeili G, Fazeli-Nasab B. Gastroprotective effects of aqueous and hydroalcholic extract of Scrophularia striata on ethanol-induced gastric ulcers in rats. Braz J Microbiol. 2017;9(5):8493.

6. Nascimento GG, Locatelli J, Freitas PC, Silva GL. Antibacterial activity of plant extracts and phytochemicals on antibiotic-resistant bacteria. Braz J Microbiol. 2000;31(4):247-56. doi: 10.1590/S151783822000000400003
7. Saeidi S, Fazeli-Nasab B. Evaluation of antibacterial and antifungal activity of various extracts of the Rhazya stricta , Capparis spinosa , cretica Cressa. New Find Vet Microbiol. 2019;2(1):57-66.

8. Abdel-Hady AA, El-Nahas H, El Nabarawy S, Abdel Raouf H. Evaluation of the Antioxidant Activity and the Acute Oral Toxicity of Three Plant Extracts on Albino Mice. Middle East J Appl Sci. 2014;4(2):207-16.

9. Smith SI, Aboaba OO, Odeigha P, Shodipo K, Adeyeye JA, Ibrahim A, et al. Plasmid profile of Escherichia coli 0157: H7 from apparently healthy animals. Afr J Biotechnol. 2003;2(9):322-4. doi: 10.5897/AJB2003.000-1066.

10. Valizadeh M, Beigomi M, Fazeli-Nasab B. Antibacterial and Anti biofilm effects of ethanol and aceton leaf extract of Momordica charantia and Tecomella undulata against Acinetobacter baumannii. Int J Adv Biol Biomed Res. 2020;8(4):403-18. doi: 10.33945/sami/ijabbr.2020.4.6.

11. Keikhaie KR, Fazeli-Nasab B, Jahantigh HR, Hassanshahian M. Antibacterial Activity of Ethyl Acetate and Methanol Extracts of Securigera securidaca, Withania sominefra, Rosmarinus officinalis and Aloe vera Plants against Important Human Pathogens. J Med Bacteriol. 2018;7(12):13-21.

12. Tenover FC. Mechanisms of antimicrobial resistance in bacteria. Am J Med. 2006;119(6 Suppl 1):S3-10. discussion S62-70. doi: 10.1016/j.amjmed.2006.03.011. [PubMed:16735149].

13. Lacmata ST, Kuete V, Dzoyem JP, Tankeo SB, Teke GN, Kuiate JR. Antibacterial activities of selected Cameroonian plants and their synergistic effects with antibiotics against bacteria expressing MDR phenotypes. Evidence-Based Complement Altern Med. 2012;8(4):40318. doi: 10.1155/2012/623723. [PubMed: 22474511]. [PubMed Central: PMC3304440].

14. Fiamegos YC, Kastritis PL, Exarchou V, Han H, Bonvin AM, Vervoort J, et al. Antimicrobial and efflux pump inhibitory activity of caffeoylquinic acids from Artemisia absinthium against gram-positive pathogenic bacteria. PLoS One. 2011;6(4). e18127. doi: 10.1371/journal.pone.0018127. [PubMed: 21483731]. [PubMed Central: PMC3070693].

15. Borges-Walmsley MI, McKeegan KS, Walmsley AR. Structure and function of efflux pumps that confer resistance to drugs. Biochem J. 2003;376(Pt 2):313-38. doi: 10.1042/BJ20020957. [PubMed: 13678421]. [PubMed Central: PMC1223791].

16. Ebrahimabadi AH, Ebrahimabadi EH, Djafari-Bidgoli Z, Jookar Kashi F, Mazoochi A, Batooli H. Composition and antioxidant and antimicrobial activity of the essential oil and extracts of Stachys inflata Benth from Iran. Food Chem. 2010;119(2):452-8. doi: 10.1016/j.foodchem.2009.06.037.

17. Ghasemi Pirbalouti A, Malekpoor F, Enteshari S, Yousefi M, Momtaz $\mathrm{H}$, Hamedi B. Antibacterial activity of some folklore medicinal plants used by Bakhtiari tribal in Southwest Iran. Int J Biol. 2010;2(2). doi: 10.5539/ijb.v2n2p55.

18. Nasab-Fazeli B, Sirousmehr A, Mirzaei N, Solimani M. Evaluation of total phenolic, flavenoeid content and antioxidant activity of Leaf and Fruit in 14 different genotypes of Ziziphus mauritiana L. in south of Iran. Eco-Phytochem J Med Plants. 2017;4(4):1-4.

19. Bazzaz BS, Haririzadeh G. Screening of Iranian Plants for Antimicrobial Activity. Pharmaceutical Biology. 2008;41(8):573-83. doi: 10.1080/13880200390501488.

20. Bonjar S. Evaluation of antibacterial properties of some medicinal plants used in Iran. J Ethnopharmacol. 2004;94(2-3):301-5. doi: 10.1016/j.jep.2004.06.007. [PubMed: 15325735].

21. Fazeli-Nasab B, Mirzaei N. Evaluation of Total Phenol and Flavonoid Content in a Wide Range of Local and imported Plants. Jlam Univ Med Sci. 2018;26(2):141-54. doi: 10.29252/sjimu.26.2.141.

22. Fazeli MR, Amin G, Ahmadian Attari MM, Ashtiani H, Jamalifar $\mathrm{H}_{\text {, }}$ Samadi N. Antimicrobial activities of Iranian sumac and avishan-e shirazi (Zataria multiflora) against some food-borne bacteria. Food Control. 2007;18(6):646-9. doi:10.1016/j.foodcont.2006.03.002. 
23. Jaberian H, Piri K, Nazari J. Phytochemical composition and in vitro antimicrobial and antioxidant activities of some medicinal plants. Food Chem. 2013;136(1):237-44. doi: 10.1016/j.foodchem.2012.07.084. [PubMed: 23017418].

24. Khosravi AD, Behzadi A. Evaluation of the antibacterial activity of the seed hull of Quercus brantii on some gram negative bacteria. PakJ Med Sci. 2006;22(4):429-32.

25. Behmanesh B, Heshmati GA, Mazandarani M, Rezaei MB, Ahmadi AR, Ghaemi EO, et al. Chemical Composition and Antibacterial Activity from Essential Oil of Artemisia sieberi Besser subsp. Sieberi in North of Iran. Asian J Plant Sci. 2007;6(3):562-4. doi: 10.3923/ajps.2007.562.564.

26. Lu Z, Dockery CR, Crosby M, Chavarria K, Patterson B, Giedd M. Antibacterial Activities of Wasabi against Escherichia coli O157:H7 and Staphylococcus aureus. Front Microbiol. 2016;7:1403. doi: 10.3389/fmicb.2016.01403. [PubMed: 27708622]. [PubMed Central: PMC5030237]

27. Eshaghi Najafabadi R, Mohammadi M, Yousefi M, Habibi Z. Chemical Composition and Antibacterial Activity of Essential Oils from Flowers, Seeds and Stems ofHeracleum rechingeri (Manden) from Iran. J Essent Oil Bearing Plants. 2011;14(6):746-50. doi: 10.1080/0972060x.2011.10643998.

28. Darabpour E, Poshtkouhian Bavi A, Motamedi H, Seyyed Nejad SM. Antibacterial activity of different parts of Peganum harmala L. growing in Iran against multi-drug resistant bacteria. EXCLI J. 2011;10:252-63. [PubMed: 29033706]. [PubMed Central: PMC5611620].

29. Shayan S, Bokaeian M, Shahraki S, Saeidi S. Prevalence of AmpC and ESBL Producing E. coli and Antibacterial Effect of Allim sativum on Clinical Isolates Collected from Zahedan Hospitals. Zahedan J Res Med Sci. 2014;16(4):6-10.

30. Hassanshahian M, Bayat Z, Saeidi S, Shiri Y. Antimicrobial activity of Trachyspermum ammi essential oil against human bacterial. Int J Adv Biol Biomed Res. 2014;2(1):18-24.

31. Fazeli-Nasab B. The effect of explant, BAP and 2,4-D on callus induction of Trachyspermum ammi. Potravinarstvo. 2018;12(1). doi: 10.5219/953.

32. Bokaeian M, Sheikh M, Shahi Z, Saeidi S. Antimicrobial activity of Hibiscus sabdariffal extract against human pathogen. Int J Adv Biol Biomed Res. 2014.

33. Thulasi G, Amsaveni V. Antibacterial activity of Cassia auriculata against ESBL producing E. coli from UTI patients. Int J Microbiol Res. 2012;3(1):24-9.

34. Dhama K, Tiwari R, Chakrabort S, Saminathan M, Kumar A, Karthik $\mathrm{K}$, et al. Evidence Based Antibacterial Potentials of Medicinal Plants and Herbs Countering Bacterial Pathogens Especially in the Era of Emerging Drug Resistance: An Integrated Update. Int J Pharmacol. 2014;10(1):1-43. doi:10.3923/ijp.2014.1.43.

35. Mostafa AA, Al-Askar AA, Almaary KS, Dawoud TM, Sholkamy EN, Bakri MM. Antimicrobial activity of some plant extracts against bacterial strains causing food poisoning diseases. SaudiJBiol Sci.2018;25(2):3616. doi: 10.1016/j.sjbs.2017.02.004. [PubMed: 29472791]. [PubMed Central: PMC5815983].

36. Avaei A, Mohamadi Sani A, Mahmoodzadeh Vaziri B. Chemical composition and antimicrobial effect of the essential oil of Zataria multiflora Boiss endemic in Khorasan-Iran. Asian Pac JTrop Dis. 2015;5(3):1815. doi: 10.1016/s2222-1808(14)60649-6.

37. Meda A, Lamien CE, Romito M, Millogo J, Nacoulma OG. Determination of the total phenolic, flavonoid and proline contents in Burkina Fasan honey, as well as their radical scavenging activity. Food Chem. 2005;91(3):571-7. doi: 10.1016/j.foodchem.2004.10.006.

38. Halpern SL. Sources and consequences of seed size variation in Lupinus perennis (Fabaceae): adaptive and non-adaptive hypotheses. Am J Bot. 2005;92(2):205-13. doi: 10.3732/ajb.92.2.205. [PubMed: 21652397].

39. Nemati Niko Z, Ghajarbeygi P, Mahmoudi R, Mousavi S, Mardani K. Inhibitory Effects of Aloe Vera Gel Aqueous Extract and L. casei Against E. coli in Yoghurt. J Biol Today's World. 2016;5(9). doi: 10.15412/j.jbtw.01050901.
40. Barzegar H, Alizadeh Behbahani B, Mehrnia MA. Quality retention and shelf life extension of fresh beef using Lepidium sativum seed mucilage-based edible coating containing Heracleum lasiopetalum essential oil: an experimental and modeling study. Food Sci Biotechnol. 2020;29(5):717-28. doi: 10.1007/s10068-019-00715-4. [PubMed 32419970]. [PubMed Central: PMC7221043].

41. Mashreghi M, Niknia S. The Effect of Peganum harmala and Teucrium polium Alcoholic Extracts on Growth of Escherichia coli O157. Jundishapur J Microbiol. 2012;5(3):511-5. doi: 10.5812/jjm.3665.

42. Bachir RG, Benali M. Antibacterial activity of the essential oils from the leaves of Eucalyptus globulus against Escherichia coli and Staphylococcus aureus. Asian Pac J Trop Biomed. 2012;2(9):739-42. doi 10.1016/S2221-1691(12)60220-2. [PubMed: 23570005]. [PubMed Central: PMC3609378].

43. Bameri Z, Amini-Boroujeni N, Bokaeian M, Saeidi S, Jalaladdini M, Bazi S. Antimicrobial activity of Cyminum cuminum against biofilm E. coli. Int Res J Appl Basic Sci. 2013;6(3):286-8.

44. Hassannejad N, Bahador A, Rudbari NH, Modarressi MH, Parivar K. In vivo antibacterial activity of Zataria multiflora Boiss extract and its components, carvacrol, and thymol, against colistin-resistant Acinetobacter baumannii in a pneumonic BALB/c mouse model. $J$ Cell Biochem. 2019;120(11):18640-9. doi: 10.1002/jcb.28908. [PubMed 31338900].

45. Poovendran P. Antimicrobial activity of Mirabilis Jalapa and Dichrotachys cinerea against biofilm and extended spectrum of beta lactamase (ESBL) producing uropathogenic Escherichia coli. Afr J Microbiol Res. 2011;5(22). doi: 10.5897/ajmr11.116.

46. Amirkaveei S, Behbahani BA. Antimicrobial effect of mangrove extract on Escherichia coli and Penicillium digitatum. International Conference on Food Engineering and Biotechnology. 2011. p. 185-8.

47. Sahraei S, Azizi A. Evaluation of the effect of antimicrobial activity of ethanol extract of Calotropis procera in Extended Spectrum BetaLactamase Producing E. coli. Int J Adv Biol Biomed Res. 2014;2(3):764-8.

48. Growther L, Sukritha K, Savitha N, Andrew NS. Antibacterial activity of Punica granatum peel extracts against Shiga toxin producing E. coli. Int J Life Sci Bt and Pharm Res. 2012;4:1-11.

49. Voravuthikunchai SP, Limsuwan S. Medicinal plant extracts as antiEscherichia coli O157:H7 agents and their effects on bacterial cell aggregation. J Food Prot. 2006;69(10):2336-41. doi: 10.4315/0362-028X69.10.2336. [PubMed: 17066910].

50. Trabelsi A, El Kaibi MA, Abbassi A, Horchani A, Chekir-Ghedira L, Ghedira K. Phytochemical Study and Antibacterial and Antibiotic Modulation Activity of Punica granatum (Pomegranate) Leaves. Scientifica (Cairo). 2020;2020:8271203. doi: 10.1155/2020/8271203. [PubMed: 32318311]. [PubMed Central: PMC7150692].

51. Chukwuka KS, Ikheloa JO, Okonko IO, Moody JO, Mankinde TA. The antimicrobial activities of some medicinal plants on Escherichia coli as an agent of diarrhea in livestock. Adv Appl Sci Res. 2011;2(4):37-48.

52. Dongarwar A, Nimbekar T, Parshuramkar T, Indurwade N. Preparation and Evaluation of Herbal Formulation Using Natural Extract. Chem Methodol. 2019;3(4):451-6.

53. Asghar MA, Zahir E, Shahid SM, Khan MN, Asghar MA, Iqbal J, et al. Iron, copper and silver nanoparticles: Green synthesis using green and black tea leaves extracts and evaluation of antibacterial, antifungal and aflatoxin B1 adsorption activity. Lwt. 2018;90:98-107. doi: 10.1016/j.lwt.2017.12.009.

54. Ramadhan M, Sabarudin A, Safitri A. In Vitro Anti-microbial Activity of Hydroethanolic Extracts of Ruellia tuberosa L.: Eco-friendly Basedproduct Against Selected Pathogenic Bacteria. IOP Conference Series: Earth and Environmental Science. 2019.

55. Sawhney R, Berry V, Kumar A. Inhibitory Activity of Rubia cordifolia plant extract against ESBL producing Urinary E. coli isolates.J Pharm Res. 2012;5(3):1328-30.

56. Slusarenko AJ, Patel A, Portz D. Control of plant diseases by natural products: Allicin from garlic as a case study. Sustainable disease 
management in a European context. . Springer; 2008. p. 313-22. doi: 10.1007/978-1-4020-8780-6_10.

57. Rahimi V, Hekmatimoghaddam S, Jebali A, Khalili Sadrabad E, Akrami Mohajeri F. Chemical Composition and Antifungal Activity of Essential Oil of Zataria Multiflora. J Nutr Food Secur. 2019;4(1):1-6. doi: 10.18502/jnfs.v4i1.394.

58. Mitic V, Jovanovic O, Stankov-Jovanovic V, Zlatkovic B, Stojanovic G. Analysis of the essential oil of Teucrium polium ssp. capitatum from the Balkan Peninsula. Nat Prod Commun. 2012;7(1):83-6. [PubMed: 22428254].

59. Daroui-Mokaddem H, Kabouche A, Bouacha M, Soumati B, El-Azzouny A, Bruneau C, et al. GC/MS analysis and antimicrobial activity of the essential oil of fresh leaves of Eucalytus globulus, and leaves and stems of Smyrnium olusatrum from Constantine (Algeria). Nat Prod Commun. 2010;5(10):1669-72. [PubMed: 21121270].

60. Rana VS. Chemical composition of the essential oil of Cuminum cyminum L. seeds from Western India. J Med Plants By-Product. 2014;3(2):207-10.

61. Mohammed SI, Vishwakarma KS, Maheshwari VL. Evaluation of Larvicidal Activity of Essential Oil from Leaves of Coccinia grandis against Three Mosquito Species. J Arthropod Borne Dis. 2017;11(2):22635. [PubMed: 29062847]. [PubMed Central: PMC5641611].

62. Olufunke MD, Kasali AA, Olusegun E. Constituents of theSpondias mombinLinn and the Comparison between its Fruit and Leaf essential oils. J Essent Oil Bearing Plants. 2003;6(3):148-52. doi: 10.1080/0972 060x.2003.10643343.

63. Sonibare MA, Ogunwande IA, Walker TM, Setzer WN, Soladoye MO, Essien E. Volatile Constituents of Ficus Exasperata Leaves. Nat Prod
Commun. 2019;1(9). doi: 10.1177/1934578x0600100912.

64. Kouame BKFP, Toure D, Kablan L, Bedi G, Tea I, Robins R, et al. Chemical Constituents and Antibacterial Activity of Essential Oils from Flowers and Stems of Ageratum conyzoides from Ivory Coast. Records Nat Prod. 2018;12(2):160-8. doi: 10.25135/rnp.22.17.06.040.

65. Moronkola DO, Ogukwe C, Awokoya KN. Chemical compositions of leaf and stem essential oils of Calotropis procera Ait R. Br [Asclepiadaceae]. Der Chemi Sinica. 2011;2(2):255-60.

66. Zin N, Rahimi W, Bakar NA. A Review of Quercus infectoria (Olivier) Galls as a Resource for Anti-parasitic Agents: In Vitro and In Vivo Studies. Malays J Med Sci. 2019;26(6):19-34. doi: 10.21315/mjms2019.26.6.3. [PubMed: 31908584]. [PubMed Central: PMC6939732].

67. Sukumaran S, Kiruba S, Mahesh M, Nisha SR, Miller PZ, Ben CP, et al. Phytochemical constituents and antibacterial efficacy of the flowers of Peltophorum pterocarpum (DC.) Baker ex Heyne. Asian Pac J Trop Biomed. 2011;4(9):735-8. doi: 10.1016/s1995-7645(11)60183-1.

68. Adewuyi AM, Akangbe YT, Animasaun DA, Durodola FA, Bello OB. Terminalia avicennioides as a potential candidate for pharmaceutical industry: a review. Res J Pharm Biol Chem Sci. 2015;6(2):748-54.

69. Muhaisen HMH. Chemical constituents from the bark of Lannea acida rich (anacardiaceae). Scholars Res Lib. 2013;5(5):88-96.

70. Joshi RK. Chemical Composition, In Vitro Antimicrobial and Antioxidant Activities of the Essential Oils of Ocimum Gratissimum, O. Sanctum and their Major Constituents. Indian J Pharm Sci. 2013;75(4):45762. doi: 10.4103/0250-474X.119834. [PubMed: 24302801]. [PubMed Central: PMC3831728].

71. Akhtar M, Ali M, Mir SR, Singh O. New anthraquinones from Rubia cordifolia roots. Indian J Chem. 1945;45B(8). 
Table 1. In Vitro Activity of the Medicinal Plants Affecting Escherichia coli

\begin{tabular}{|c|c|c|c|c|}
\hline Scientific Name & Family Name & Part Used & Result & Ref \\
\hline Stachys inflata Benth & Lamiaceae & Aerial parts & $\begin{array}{l}\text { The inhibition zone diameter of methanol extract of this } \\
\text { plant was } 11 \mathrm{~mm} \text {, and the MIC of methanol extract was } 500 \\
\mathrm{mg} / \mathrm{ml} \text {, and MIC of a-Terpineol and Linalool were } 500 \text { and } 125 \\
\mathrm{mg} / \mathrm{mL} \text {, respectively. }\end{array}$ & (16) \\
\hline Heracleum lasiopetalum Boiss & Apiaceae & Fruit & $\begin{array}{l}\text { Antibacterial activity of ethanol extract and essential oil were } \\
18 \text { and } 17 \mathrm{~mm} \text {, respectively. MIC of the ethanol extract and } \\
\text { essential oil were } 156.25 \text { and } 39 \mu \mathrm{g} / \mathrm{mL} \text {, respectively. }\end{array}$ & (17) \\
\hline Ziziphora teniur $\mathrm{L}$. & Lamiaceae & Leaves & $\begin{array}{l}\text { The antibacterial activity of the ethanol extract was } 18 \mathrm{~mm} \\
\text { using agar diffusion assay (100 } \mu \mathrm{g} / \text { disc }) \text {. MIC of the ethanol } \\
\text { extract was } 625 \mu \mathrm{g} / \mathrm{mL} \text {. }\end{array}$ & $(17,18)$ \\
\hline Euphorbia helioscopa $\mathrm{L}$. & Euphorbiaceae & Aerial Parts & $\begin{array}{l}\text { In each plate, one positive control (gentamycin } 0.8 \mathrm{mg} / 0.2 \\
\mathrm{~mL} \text { and one negative control (methanol } 0.2 \mathrm{~mL} \text { ) were } \\
\text { included. Zones of inhibition were measured, and } \\
\text { antimicrobial activities of the extracts were measured. }\end{array}$ & $(19)$ \\
\hline Euphorbia microsciadia Boiss & Euphorbiaceae & Aerial Parts & $\begin{array}{l}\text { In each plate, one positive control (gentamycin } 0.8 \mathrm{mg} / 0.2 \mathrm{~mL} \\
\text { and one negative control (methanol } 0.2 \mathrm{ml} \text { ) were included. }\end{array}$ & (19) \\
\hline Centaurea cyanus $\mathbf{L}$ & Asteraceae & Total parts & $\begin{array}{l}\text { In each plate, one positive control (gentamycin } 0.8 \mathrm{mg} / 0.2 \mathrm{~mL} \\
\text { and one negative control (methanol } 0.2 \mathrm{ml} \text { ) were included. }\end{array}$ & (19) \\
\hline Verbascum speciosum Schrad & Scrophulariaceae & Leaves & $\begin{array}{l}\text { In each plate, one positive control (gentamycin } 0.8 \mathrm{mg} / 0.2 \mathrm{~mL} \\
\text { and one negative control (methanol } 0.2 \mathrm{ml} \text { ) were included. }\end{array}$ & $(19)$ \\
\hline Apium graveolens & Apiaceae & Leaves & $\begin{array}{l}\text { Inhibition zone diameter was } 7-9 \mathrm{~mm} \text { using agar } \\
\text { well-diffusion bioassay ( } 2 \mathrm{mg} / \text { well). }\end{array}$ & (20) \\
\hline Trigonella foenum-graecum & Leguminosaepapilionoideae & Seeds & $\begin{array}{l}\text { Inhibition zone diameter was }>15 \mathrm{~mm} \text { using agar } \\
\text { well-diffusion bioassay ( } 2 \mathrm{mg} / \text { well }) \text {. }\end{array}$ & (20) \\
\hline Ziziphus ziziphus & Rhamnaceae & Fruit & $\begin{array}{l}\text { Inhibition zone diameter was 10-14 mm using agar well } \\
\text { diffusion bioassay ( } 2 \mathrm{mg} / \text { well). }\end{array}$ & $(18,20,21)$ \\
\hline Rhus coriaria & Anacardiaceae & Fruit & $\begin{array}{l}\text { Antibacterial activity of the ethanolic extracts using the disc } \\
\text { and well diffusion assays was } 17 \text { and } 24 \mathrm{~mm} \text {, respectively. The } \\
\text { zone of inhibition was } 17 \mathrm{~mm} \text { through disc diffusion assay. } \\
\text { MIC of extracts was } 0.20 \% \text {. }\end{array}$ & $(22)$ \\
\hline Funmaria vaillantii & Fumariaceae & Flowers and stems & $\begin{array}{l}\text { The zone of inhibition using the agar diffusion test was } 11 \\
\text { mm and MIC was } 125 \mu \mathrm{g} / \mathrm{mL} \text {. }\end{array}$ & (23) \\
\hline Quercus brantii & Fagaceae & Fruit & The inhibition zone diameter was $12 \mathrm{~mm}$. & $(24)$ \\
\hline Artemisia siberi & Asteraceae & Aerial parts & The diameter of the inhibitory zone diameter was $12 \mathrm{~mm}$. & (25) \\
\hline Wasabia japonica & Brassicaceae & Total part & $\begin{array}{l}\text { The results indicated that the MIC of wasabi against E. coli } \\
\text { O157:H7 and S. aureus was } 1 \% \text { (equal to } 10 \mathrm{mg} / \mathrm{mL} \text { ) and } 4 \% \text {, } \\
\text { respectively. }\end{array}$ & $(26)$ \\
\hline Peganumharmala & Nitrariaceae & Fruit & MIC was $5 \mathrm{mg} / \mathrm{mL}$. & $(27)$ \\
\hline Peganumharmala & Nitrariaceae & Root & MIC was $0.625 \mathrm{mg} / \mathrm{mL}$. & $(27,28)$ \\
\hline Allium sativum & Amaryllidaceae & Fruit & $\begin{array}{l}\text { The inhibition zone diameter around the discs varied from } 17 \\
\text { - } 35 \mathrm{~mm} \text {, indicating that all } 13 \mathrm{AmpC} \text { positive isolates (100\%) } \\
\text { were sensitive to garlic extract. One out of } 13 \text { E. coli sequesters } \\
\text { had a MIC of } 2.5 \mathrm{mg} / \mathrm{ml} \text { for alcoholic distillate of } \text { A. sativum. } \\
\text { The highest MIC and MBC values of the alcoholic distillate of } \\
\text { A. sativum were } 5 \mathrm{mg} / \mathrm{ml} \text { and } 10 \mathrm{mg} / \mathrm{mL} \text {, respectively. The } \\
\text { highest and lowest MIC of AmpC positive E. coli isolates were } \\
\text { determined to be }>256 \text { and } 16 \mu \mathrm{g} / \mathrm{mL} \text {, respectively. }\end{array}$ & (29) \\
\hline Trachyspermum ammi & Apiaceae & Seed & The highest MIC of the needful oil was $100 \mathrm{ppm}$ against E. coli. & $(18,30,31)$ \\
\hline Hibiscus sabdariffal & Malvaceae & Flower & $\begin{array}{l}\text { The highest MIC value was detected to be } 20 \mathrm{mg} / \mathrm{mL} \text { against } \\
\text { two E. coli isolates. }\end{array}$ & $(32)$ \\
\hline Cassia auriculata & Fabaceae & Leaves & $\begin{array}{l}\text { The MIC and MBC of ethyl acetate extract of the leaves and } \\
\text { flowers were measured. The highest MIC was } 50-125 \mathrm{mg} / \mathrm{mL} \text {. }\end{array}$ & (33) \\
\hline Artichoke & Asteraceae & Leaves & $\begin{array}{l}\text { The results showed that the inhibition zone diameter of the } \\
\text { ethanolic, methanolic, and estrogenic extracts of leaves was } \\
11 \mathrm{~mm} \text {, while for the ethanolic and methanol extracts of the } \\
\text { stem, this rate was equal to } 8-14 \text { and } 11 \mathrm{~mm} \text {, respectively }\end{array}$ & (34) \\
\hline Punica granatum & Lythraceae & Peel & $\begin{array}{l}\text { The PIC of the ethanol extract prepared from peel was } 14.2 \pm \\
0.61\end{array}$ & (35) \\
\hline
\end{tabular}




\begin{tabular}{|c|c|c|c|c|}
\hline Zataria multiflora & Lamiaceae & Leaves & $\begin{array}{l}\text { The correlation coefficient of the concentration of essential } \\
\text { oil of } Z \text {. multiflora with the logarithm of the bacteria was } \\
\text { studied at temperatures of } 4 \text {, and } 10^{\circ} \mathrm{C} \text { and the results were } \\
0.701 \text { and } 0.599 \text {, indicating that by increasing the essential oil } \\
\text { concentration, the growth rate of the bacteria during the } \\
\text { storage period is reduced and efficacy of the necessary oil on } \\
\text { the growth of bacteria is significant. }\end{array}$ & (36) \\
\hline Honey & & & $\begin{array}{l}\text { The results showed that the inhibitory zone diameter of } \\
\text { honey, licorice, honey, apples, and honey are } 1 \pm 13,5 / 0 \pm 12 \text {, } \\
\text { and } 5 / 0 \pm 9 \mathrm{~mm}\end{array}$ & (37) \\
\hline Rose & Rosales & Leaves & $\begin{array}{l}\text { The inhibitory zone diameter of the ethanolic extract of rose } \\
\text { was } 14 \mathrm{~mm} \text {, and its MIC was } 25 \mathrm{mg} \text {. }\end{array}$ & $(38,39)$ \\
\hline Aloe vera & Asphodelaceae & Leaves & MIC was $50 \mu \mathrm{g}$. & (39) \\
\hline Fennel Bakhtiari & - & - & $\begin{array}{l}\text { MIC and MBC of alcoholic extract of Bakhtiari fennel against } \\
\text { E. coli were } 3.12 \mathrm{mg} / \mathrm{ml} \text { and zero, respectively. }\end{array}$ & $(40)$ \\
\hline Peganum harmala & Nitrariaceae & Leaves & $\begin{array}{l}\text { Compared with the controls, there was no significant } \\
\text { difference } n \text { the efficacy of the P. harmala juice on microbial } \\
\text { growth. }\end{array}$ & $(41,42)$ \\
\hline Eucalyptus globulus & Myrtaceae & Leaves & $\begin{array}{l}\text { The results indicated that essential oil of the leaves of E. } \\
\text { globulus has an antibacterial effect against E. coli and } S \text {. } \\
\text { aureus. }\end{array}$ & $(41,42)$ \\
\hline Cyminum cuminum & Apiaceae & Seed & $\begin{array}{l}\text { Ethanol extract of seeds showed antimicrobial activity } \\
\text { against the E. coli biofilm. }\end{array}$ & $(31,43)$ \\
\hline Zataria multiflora & Lamiaceae & Leaves & The extract represented inhibitory activity against $E$. coli. & $(44)$ \\
\hline Coccinia grandis & Cucurbitaceae & Leaves & $\begin{array}{l}\text { Aqueous, acetone, and ethanol extracts of the leaves of C. } \\
\text { grandis were examined for antibacterial effect using the agar } \\
\text { well diffusion method. Ethanol extract of the leaves } \\
\text { displayed antibacterial effect against biofilm producing } \\
\text { strains UPEC } 17 \text { and } 82 \text {, whereas the aqueous and acetone } \\
\text { extracts displayed antimicrobial effect only against UPEC } 57 \text {. } \\
\text { Ethanol extract of levees showed inhibitory action against } \\
\text { ESBL producing UPEC } 87 \text { and 96, while the aqueous extract } \\
\text { inhibited the growth of only UPEC } 85 \text {. }\end{array}$ & $(45,46)$ \\
\hline Avicenna Marina & Acanthaceae & - & $\begin{array}{l}\text { The glycerol extract of Avicenna Marina showed inhibitory } \\
\text { activity against } E \text {. coli and P. digitatum. }\end{array}$ & $(45,46)$ \\
\hline Calotropis procera & Apocynaceae & Leave & $\begin{array}{l}\text { The results illustrated that a total of } 30 \text { of } 80 \text { (37.5\%) isolates } \\
\text { harbored ESBL enzymes. }\end{array}$ & $(47)$ \\
\hline Punica granatum & Lythraceae & Leave & $\begin{array}{l}\text { MIC of Punica granatum was } 4.0 \mathrm{mg} / \mathrm{ml} \text {, which showed a good } \\
\text { antibacterial activity against Shiga toxin produced by E. coli. }\end{array}$ & $(48)$ \\
\hline Punica granatum & Lythraceae & Leave & MIC was 0.49 to $1.95 \mathrm{mg} / \mathrm{ml}$ and $\mathrm{MBC}$ was 1.95 to $3.91 \mathrm{mg} / \mathrm{ml}$. & $(49)$ \\
\hline Punica granatum & Pomegranate & Leave & $\begin{array}{l}\text { In this study, six extracts were prepared from the powdered } \\
\text { leaves of } P \text {. granatum. The MIC was found to be from } 0.5 \text { to } \\
20.07 \% \text {. The highest MIC was obtained using the aqueous } \\
\text { extract and the lowest was related to the ethyl acetate extract. }\end{array}$ & (50) \\
\hline Ocimum gratissimum & Lamiaceae & & $\begin{array}{l}\text { The MIC presented by Ocimum gratissimum against the } E \text {. coli } \\
\text { strains was } 20,000 \mu \mathrm{g} / \mathrm{mL} \text {. }\end{array}$ & (51) \\
\hline Butea monosperma & Fabaceae & Flower & $\begin{array}{l}\text { The extract exhibited antibacterial activity against } E \text {. coli and } \\
\text { S. aureus. }\end{array}$ & $(52)$ \\
\hline Physalis pubescens & Solanaceae & Leaves & $\begin{array}{l}\text { The extracts exhibited the highest inhibitory diameter zone } \\
\text { of } 12.5 \text { to } 13.6 \mathrm{~mm} \text {. }\end{array}$ & $(53)$ \\
\hline Ruellia tuberosa $\mathrm{L}$. & Acanthaceae & Root & $\begin{array}{l}\text { The inhibitory diameter zone against } E \text {. coli, was } 7,7,7,10.75 \text {, } \\
11.00 \text {, and } 15.00 \mathrm{~mm} \text { for the concentrations of } 5,10,20,50,75 \text {, } \\
\text { and } 100 \%(\mathrm{v} / \mathrm{v}) \text {, respectively. }\end{array}$ & $(54)$ \\
\hline Rubia cordifolia & Rubiaceae & Root & $\begin{array}{l}\text { The plant could be a potential candidate for an alternative } \\
\text { antibacterial agent to combat the invasion of drug-resistant } \\
\text { organisms. }\end{array}$ & (55) \\
\hline
\end{tabular}

Abbreviations: E. coli: Escherichia coli; MBC, minimum bactericidal concentration; MIC, minimum inhibitory concentration. 